\title{
The evolution of the Polish government bond market
}

PIOTR BARTKIEWICZ, MA*

Preliminary communication**

JEL: H63, G14

https://doi.org/10.3326/pse.45.1.5

\footnotetext{
* The author would like to thank the two anonymous referees and Michał Rubaszek for useful comments and suggestions.

${ }^{* *}$ Received: September 26, 2020

Accepted: December 13, 2020

Piotr BARTKIEWICZ

SGH Warsaw School of Economics, Collegium of Economic Analysis, ul. Madalińskiego 6/8 02-513

Warszawa, Poland

e-mail: bartkiewicz.p@gmail.com

ORCiD: 0000-0003-0838-2536
} 
Abstract

Poland's marketable government debt has grown from essentially zero in the early 1990s to USD 180 bn by 2019, with a wide range of maturities and security types. The aim of the article is to describe the long-term trends in the Polish sovereign local currency debt. Changes in its composition, maturity profile and ownership structure are analysed. The Ministry of Finance's databases on bond transactions and secondary market activity are used. Since early 2000s the market has become less fragmented and the ownership structure has shifted considerably in reaction to global and national factors. Debt management strategy has stabilized the market and reduced frictions. Countries developing their local currency bond markets should be encouraged to avoid market fragmentation and concentrate on selected benchmark issues. Creating a functioning local currency bond market is essential in avoiding the so called "original sin", but must be part of a broader institutional push.

Keywords: fixed income, bond market, market structure, foreign investors

\section{INTRODUCTION}

Government bonds are one of the most important financial asset classes and play an important role in government policy and economic decisions made by public and private agents. This is also the case in Poland, where public debt amounted to $46.1 \%$ of GDP in 2019. This debt consists in large part of government bonds of various types, maturities and currencies. Due to the relatively large size of the Polish economy and its high-income (but also emerging-market) status, it constitutes a large part of popular government bond indices and is a target of investing by institutional investors, both local and foreign (one notable example is the JP Morgan EM Local Currency Bond Index). Price discovery occurring in the market is also of interest to fiscal and monetary policy and researchers as it informs interest rate expectations, term and risk premia, as well as inflation expectations (mostly indirectly). The development of a local currency government bond market (and, by extension, corporate debt market as well) is an important step in achieving financial maturity and promotes economic growth (Wurgler, 2000; Fabozzi, 2005; Prasad, Rajan and Zingales, 2009). This is because of the need to avoid what is called "original sin", i.e. borrowing in foreign currency and the resulting mismatch between assets and liabilities as well as revenues and expenditures (for more details see Eichengreen, Hausmann and Panizza, 2003, 2007; McKinnon and Schnabl, 2004).

The development of the Polish bond market has been researched since its inception (the mid-1990s) and multiple studies regarding its organisation, ownership structure and information content have emerged. A succinct summary of its evolution until 2000 is presented by Klimek (1998), Wasilewska (1998) and Babczuk (2002). The role of the bond market for financing government deficit was discussed by Klimek (1998), Wasilewska and Korczak (1998), Zembura (2006), and Ciak and Górniewicz (2010). Ziarko-Siwek (2012) conducted an event study on 
the impact of primary market sales of government bonds on the prices on the secondary market. The ownership structure of the bond market has been studied in the post-crisis period, for example, by Banaszewska (2015). More typical is the research interest in the influence of external factors on the Polish bond market, typically considered as one of many EM bond markets (see: Rai and Suchanek, 2014; Bowman, Londono and Spinoza, 2015; Fratzscher, Lo Duca and Straub, 2018). A regular update on the basic features of the Polish bond market is provided by both the National Bank of Poland in its annual reports on financial market developments (NBP, 2001; 2004 through 2018) and by the Ministry of Finance in the annually updated debt management strategy (MoF, 2019).

The aim of this article is to analyse the developments on the Polish bond markets that have taken place over the last three decades. The case of Poland is particularly instructive for many developing countries, as since 1989 a well-functioning and liquid domestic bond market has been developed almost from scratch. For the purpose of analysis we make use of the Ministry of Finance's (MoF) online datasets: the treasury bond and bill transactions database, ownership structure of public debt and detailed information on foreign investors' holdings. Overall, the databases extend from 1991 to April 2020. To include full-year data only, we cut the sample off at end-2019. The paper is based on statistical analysis and also draws from fixed income tools (calculation of modified durations for individual securities). In the paper we hypothesize that: (1) the market has attained all liquidityand information-enhancing features well before the present; (2) major institutional and macroeconomic events have had a limited impact on its key features.

This study contributes to the literature in several ways. First, it offers an up-todate analysis of the trends and events shaping the Polish government bond market. Second, it makes use of a novel dataset - the MoF's bond transaction database transformed to depict a full history of each bond issue. Third, it analyses the ownership structure of Polish government bonds using detailed data, including the characteristics of different investors' portfolios.

The paper is organized as follows. In the second section we present the basic concepts and features of bond markets as well as providing the national context for the analysis of the Polish bond market. In the third section we describe the history of the Polish bond market and its evolution over time. In the fourth section the life cycle of a bond is presented, starting from primary bond auctions, through early repurchases at the switching auction and its maturity. The subsequent section describes the current characteristics of the Polish government bond market, i.e. size, depth and structure. The last section analyses the ownership structure of the Polish bond market and its recent changes. We end the paper with a brief discussion of the results. 
A bond is a financial instrument characterized by a fixed schedule of cashflows: periodic interest payments (known as coupons) and the repayment of the principal at maturity (Fabozzi, 2005). Bonds are traded on various exchanges during which the right to the entire series of future cashflows is transferred between the parties involved in trading.

While most bonds outstanding in the world today have periodic, fixed coupon payments, other types of bonds are also popular (BIS, 2017). For zero-coupon bonds, the repayment of the principal is the only future cashflow to which the bond holder is entitled. Coupon payments of floating-rate bonds (or floaters in financial market parlance) are linked to a benchmark short-term rate (plus a premium) and reset periodically at pre-determined dates. Cashflows of inflationlinked bonds (also known as linkers) are tied to inflation. Apart from the rare and unused case of perpetual bonds, the contract expires at maturity, when the principal payment is made, and the bond is redeemed or repurchased (Fabozzi, 2005). Bonds are usually divided into maturity brackets: up to 1 year, 1-3 years, 4-6 years, 7-10 years and more than 10 years. In contrast to the situation in developed markets, emerging and frontier market issuers often issue debt denominated in foreign currencies (typically, the US dollar or the euro) to make use of lower interest rates abroad and bypass a shallow or illiquid domestic market (Jeanne, 2003; Bordo, Meissner and Stuckler, 2010). Foreign exchange (FX) debt is an important part of public debt in Poland as well.

The bond market plays an important role in the economy (Wurgler, 2000; Fabozzi, 2005). First and foremost, it allows the state to finance its borrowing needs in a transparent, flexible, efficient and cost-effective fashion. Second, it provides highquality, low-risk interest bearing assets to the private sector - i.e. to institutions and companies that either find holding such assets advantageous or are mandated by law and financial regulators to diversify portfolios (certain types of funds) or hedge interest rate risk using government bonds (banks). Third, the price discovery on the government bond market provides information to bond market participants and other economic agents. This information pertains to interest rate expectations, various risk and term premia, as well as - provided that a liquid market for inflation-linked bonds exists - inflation compensation and expectations (Gurkanyak, Sack and Wright, 2010).

For obvious reasons, bond markets are segregated geographically and inextricably tied to nation-states or currency areas. Thus, the number of government bond markets in the world is large, albeit the existence of a local bond market is typically predicated on reaching a certain level of economic development, private savings and financial depth that allows for sufficient demand for interest-bearing instruments (Burger and Warnock, 2006). Bond markets are usually characterized by size, liquidity, issuer and bondholder concentration, diversity and openness (McCauley and Remolona, 2000). 
Poland's public debt is of moderate size, constituting 46.0\% of GDP at the end of 2019 (PLN 1.05 trillion). The bulk of outstanding debt exists in the form of publicly traded bonds - as of December 31 ${ }^{\text {st }}, 2019$ there were bonds worth PLN 867 bn in all types, currencies and denominations. PLN-denominated marketable debt constituted PLN 646 bn, while marketable FX-denominated debt stood at PLN 257 bn and savings bonds offered to retail investors stood at PLN 28 bn. The remaining part of Poland's public debt is divided into loans from foreign institutions, debt incurred by local governments (in some cases in the form of bonds) and debt of various agencies and special purpose vehicles (SPVs) consolidated into the general government sector. Local currency debt constitutes 31\% of GDP. Since Poland is typically classified as an emerging market, Poland's marketable debt (both local currency and FX) is included in popular international bond market indices. Its weight typically stands at 5-10\% (depending on the instrument), ranking it among the key constituents of this asset class. For instance: Poland's weight in the JP Morgan GBI-EM Global Diversified Index stood at 10.05\%; FTSE RAFI Sovereign Emerging Markets Local Currency Bond Index weighted Polish debt at 5.36\% (although it is explicitly underweighted, i.e. weight derived from market value of debt would have amounted to $10.05 \%$, per the most recent prospectus); the iShares JP Morgan Local Currency Bond ETF weights Polish PLN debt at $5.03 \%$. Current structure of Polish public debt is presented in table 1 .

\section{TABLE 1}

Current structure of Polish public debt (billions of PLN, as of December 31 $1^{\text {st }} 2019$ )

\begin{tabular}{lr} 
Total & $\mathbf{1 , 0 6 3 . 9}$ \\
\hline central government & $\mathbf{9 7 3 . 3}$ \\
\hline domestic currency & 716.5 \\
\hline wholesale bonds & 646.1 \\
\hline retail bonds & 27.6 \\
\hline other & 42.8 \\
\hline foreign currency & 256.9 \\
\hline bonds & 193.7 \\
\hline loans & 63.2 \\
\hline other & $\mathbf{2 . 3}$ \\
\hline other central gov & $\mathbf{8 8 . 3}$ \\
\hline local governments
\end{tabular}

Source: Own elaboration based on MoF data.

As of December 2019, MoF lists 33 separate PLN-denominated bonds and 42 bonds issued in four different foreign currencies (USD, EUR, JPY, CHF). The former group is dominated by fixed-coupon bonds (19), complemented by one inflation-linked bond, 3 zero-coupon papers and 10 floaters. By value, $65 \%$ of outstanding PLN debt is kept in fixed-rate bonds, 30\% in floating-rate bonds and $4 \%$ in zero-coupon notes (the single inflation-linked bond consists of the remaining 1\%). In international comparisons, Poland stands out from its EM peers due to 
relatively large role of floating-rate debt and the paucity of inflation-linked notes, as shown by Mehrotra, Miyajima and Villar (2012), and by Cantu, Goel and Schanz (2020). For instance, in Brazil, Colombia, Mexico and South Africa inflation-protected securities constitute up to $25 \%$ of total debt outstanding. Within the foreign currency debt universe, debt issued in euro remains the most popular type (26 different bonds, 74\% of total value of FX bonds), exceeding the depth of Poland's JPY- (9 issues, 5\%), USD- (6 issues, 21\%) and CHF-denominated (1 issue, $1 \%$ ) bond markets.

\section{THE LIFE CYCLE OF A POLISH BOND}

The Polish government bond market is organized into bundles known as bond issues differentiated by maturity and coupon. The overwhelming majority of bonds begin their market life at auctions organized by the MoF, in which only certified bond dealers (i.e. around fifteen major domestic and foreign banks - the list is updated annually) are allowed to take part. Bonds bought at auction are then distributed to other purchasers and traded freely on several exchanges. In limited cases (more common for FX bonds) private placements are organized and small amounts of government bonds are sold that way.

Since 2001, government bonds are subject to partial redemption before maturity - either at switch or repurchase auctions (the latter were organized only four times over the past fifteen years). This approach offers advantages and disadvantages. On one hand, it is advantageous from the government cash management perspective, since it allows it to spread out and smooth out government outlays and reduces cash requirements upon redemption. Even though nearly zero new debt (in face value) is issued at switch auctions (which essentially swap short-dated debt for longer-duration papers), they offer a convenient opportunity to supply the private sector with government bonds of desired maturities without increasing the overall government debt level. That way, the debt manager can increase secondary market liquidity in the desired segments of the yield curve. In some cases, if repurchase happens sufficiently early, swapping new debt for old issues reduces interest payments, provided that the yield curve has shifted downwards in the preceding period. On the other hand, switch and repurchase auctions force the MoF to redeem debt at market price. Therefore, if interest rates have risen since the bond's issuance, it will likely be repurchased at a small discount. Conversely, if interest rates have fallen, it will be repurchased at a premium. Given the prevalent downward trend in interest rates in Poland, it should not come as a surprise that the former has been more common. At maturity, outstanding debt is repurchased at par. The existence of switch and repurchase auctions might thus increase the debt manager's flexibility. This practice is pursued in other countries, but rarely is it done regularly (Marchesi, 2006). Among OECD countries where switch auctions are regularly conducted are: Canada, Hungary, Israel, Mexico, Norway and Sweden (Blommenstein, Elmadag and Ejsing, 2012). For the most part it is employed in foreign currency debt more often given additional risks, e.g. exchange rate (Medeiros, Poland and Ramlogan, 2007). However, it has been proposed as a 
viable enhancement of US Treasury debt issuance and management strategy, with all the above-mentioned advantages (Garbade and Rutherford, 2007).

\section{Figure 1}

\section{Timing of switching auctions - distribution as \% of original maturity}

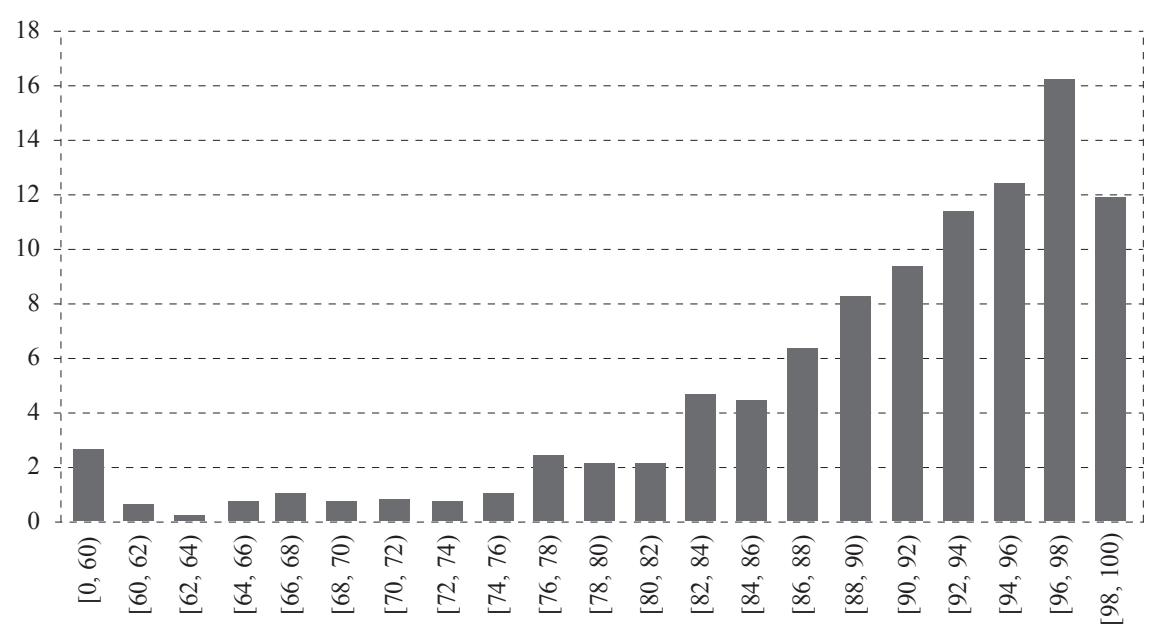

Notes: The brackets in the horizontal axis denote the time when switching auctions are performed, i.e. [96-98) groups all instances when bonds were repurchased when at least 96\%, but no more than $98 \%$ of their original maturity elapsed.

Source: Own elaboration based on MoF data.

MoF's database on bond transactions offers more details on how switch auctions impact the bond's life cycle. First, as of December 2019, not a single bond issue has ever been completely repurchased before maturity (figure 1). Conversely, for $36 \%$ of PLN-denominated bonds no switch or repurchase auctions have ever been organized - with one exception, all such bonds matured in 2009 at the latest (figure 2). Switch auctions have thus become the norm in public debt management in Poland. Second, switching auctions typically occur late in a bond's life - the median remaining time at repurchase of a bond is $7.5 \%$ of its original maturity (i.e. 16 weeks). Its distribution is negatively skewed, though, and repurchases often occur earlier, even more than a year prior to the bond's maturity. Third, among the remaining $64 \%$ of bond issues, the median amount repurchased prior to maturity is $43 \%$ of maximum stock. In several cases, more than two thirds of the supply were repurchased that way. Finally, repurchases are more common for larger bond issues - the larger the bond's supply, the more repurchases occurred and the larger the amount that was pulled from the market prior to maturity. In the extreme case of a 5-year bond maturing in April 2018 (the second-largest bond issue in the history of Polish bond market, calculated by notional value), PLN 23.4 bn (of PLN 34.9 bn outstanding) was repurchased at switch auctions, and PLN 11.5 bn redeemed at maturity. 


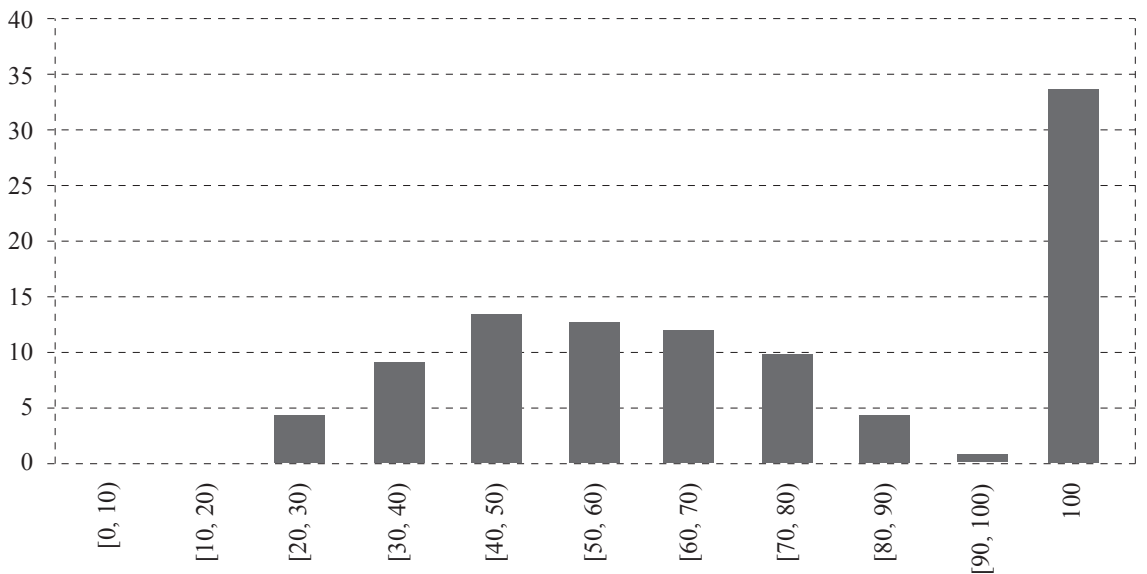

Notes: The brackets in the horizontal axis denote the total share of bond issue 's nominal value repurchased on all switching when the bond was subject to repurchases, e.g. [50, 60) groups all instances when at least $50 \%$ of total nominal value, but no more than $60 \%$ was repurchasedconversely, for this group 40-50\% of the bond's nominal value was redeemed at maturity.

Source: Own elaboration based on MoF data.

\section{THE HISTORY OF THE POLISH BOND MARKET}

Poland is a high-income country, but usually considered to be an emerging market in the context of financial market indicators (EM; Morck, Yeung and Yu, 2000; Arora and Cerisola, 2001; IMF, 2017). However, its current status and the state of both fiscal policy and bond market is a far cry from Poland's recent past. Poland emerged from the communist era with considerable external debt (see: Olszański (2002) for a detailed description), but almost no domestic debt. At the beginning of transformation, the country essentially defaulted on its domestic obligations and bequeathed the remaining liabilities vis-à-vis local banks to its successor. The ongoing institutional and economic transformation saw the development of modern public finances, but the public sector ran chronic deficits (de Crombrugghe and Lipton, 1994). From the very beginning, fiscal deficits were financed domestically, but until 1994 bank lending constituted the bulk of newly created debt (Walczyk, 2001). Non-bank, marketable debt began to grow in 1992, chiefly in the form of treasury bills of various maturities. Only in the second half of 1990s did longer-dated securities start to be issued, which coincided with the establishment of domestic financial markets (e.g. the Warsaw Stock Exchange, interbank markets, etc.) as well as a secular decline in short-term interest rates, inflation and inflation variability. A secondary market for government bonds barely existed until 2002 and 2003 - between 1998 and 2002 turnover rose from $2.7 x$ to $15 x$ of total marketable debt outstanding (NBP, 2002; 2004). This allowed fixed income securities to become more attractive. The latter factors put Poland firmly in line with other countries where the development of local currency bond markets was successful (see: Burger and Warnock, 2006; Burger, Warnock and Warnock, 2012). 
Further expansion of the PLN-denominated debt market can be associated with subsequent changes in monetary policy strategy and operations (inflation targeting was formally adopted in 2003, inflation itself was brought under control - see Rybiński (2000) and Brzoza-Brzezina (2006) for more details) and the establishment of private pension funds as an important source of demand for fixed income securities. Introduction of a larger variety of maturities and types of bonds also occurred at the turn of the century. The state's borrowing needs continued to grow in the first decade of the 2000s.

The Great Financial Crisis can be seen as another watershed moment for the Polish bond market. The impact of large-scale fiscal stimulation raised fiscal deficits and public debt considerably (IMF, 2010; Aizenmann and Pasricha, 2013), but at the same time brought several changes to the pension fund system. First, contributions to the pension funds were scaled down by $68 \%$ and replaced with a "subaccount" managed by the Social Security Institution (Łuszczyk, 2015). Second, participation in pension funds became strictly voluntary. Third, mandatory transfer of an individual's assets accumulated in the pension fund to the Social Security Institution 10 years prior to retirement was introduced. Finally, almost PLN 140 bn of bonds held by pension funds was redeemed and pension funds were barred from investing in government securities (Jakubowski, 2017). The reforms greatly reduced the build-up in debt (increased the implicit pension debt, though) and pension funds' demand for fixed income securities (IMF, 2011; Fultz, 2012; Buchholtz, Chłoń-Domińczak and Góra, 2019).

In purely nominal terms, total public debt (general government sector) rose from PLN 164 bn in 1995 to PLN 272 bn in 2000, PLN 460 bn in 2005, PLN 768 bn in 2010 and PLN 923 bn in 2015 (47.6, 36.5, 46.4, 53.1 and 51.3\% of GDP, respectively) (figure 3).

\section{Figure 3}

General government consolidated debt as percentage of GDP, historical data

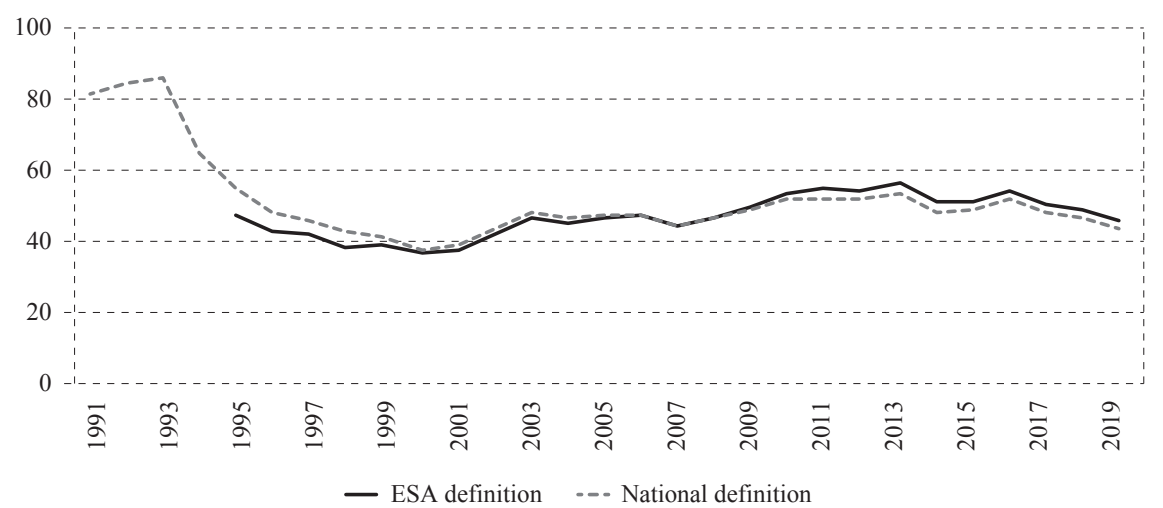

Source: Own elaboration based on Statistics Poland, Eurostat, MoF data and Walczyk (2001). 
The current structure of the Polish bond market is the result of a long evolution constituted by several concurrent shifts. First, there has been a long-lasting move away from Treasury bills (up to 1-year maturity - see figure 4, right panel) and into Treasury bonds (see figure 4, left panel). While before 1994 marketable PLNdenominated debt consisted solely of Treasury bills and more than 100 separate T-bill issues existed in the 1990s, the role of these instruments has steadily declined. Apart from a short-lived episode in 2016, the Polish MoF ceased to issue T-bills in 2013. Second, in 2000 the MoF introduced zero-coupon bonds of OK series (2-year maturity) and several separate issues have existed in circulation ever since (as of November 2018, there are 3 separate zero-coupon bond issues). Polish PLN-denominated government bonds have two separate, but interchangeable ID systems. All Treasury notes and all Treasury bills issued after July 1999 have ISINs (International Securities Identification Numbers). There is also a local nomenclature based on a six-character code with two-character series identifier and the security's maturity time in MMYY format. In recent months, MoF has issued bonds of five series: 2-year zero-coupon OK series, 5-year fixed-coupon PS series, 10-year fixed-coupon DS series, 20- and 30-year fixed-coupon WS series and floating-rate WZ series of various maturities. PLN debt outstanding as of today includes an inflation-linked IZ bond and a small privately-placed floatingrate PP issue. For instance, OK0722 is a zero-coupon bond maturing in July 2022, while DS0725 is a fixed-coupon issue with original maturity of 10 years, maturing in July 2025. Previously, MoF also issued 3-year DZ floaters and various fixedcoupon and zero-coupon bonds. A similar system applies to bonds issued for retail investors and to bonds issued by the state-owned BGK bank on behalf of the government's SPVs (IDS and FPC series). Third, the introduction of fixed-coupon bonds predates the issuance of the first floating-rate bonds only by several quarters. Over the past twenty years, the number of separate fixed-coupon bond issues has fluctuated between 12 and 31 . The number of floating-rate bond issues rose to 17 by mid-2000s and has declined to 4-9 issues in the post-crisis period. Finally, there is a relatively small amount of debt issued in the form of inflation-linked bonds (since August 2004) - there have been two such bonds in circulation.

\section{Figure 4}

Number of Treasury bond (left panel) and Treasury bill (right panel) issues outstanding
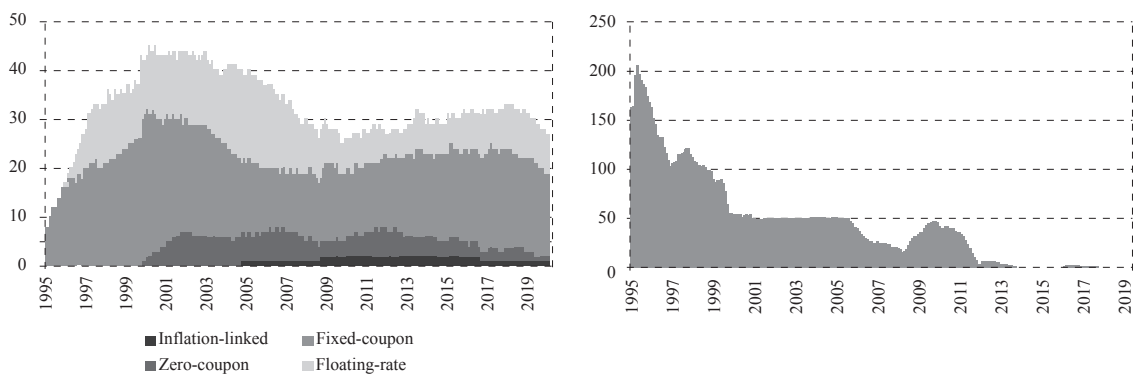

Source: Own elaboration based on MoF data. 
For the past 25 years, the Polish bond market has seen a widening of the range of available maturities and a decrease in the share of the shortest debt (up to 1 year) of note is the introduction of 15-, 20- and 30-year bonds at various points in the past. However, this shift was largely over by 2007 - since then, the average maturity of PLN-denominated bonds (be they floating - or fixed-rate) has little changed and oscillated between 4 and 4.5 years (see figures 5-6). Very similar was the stability in average duration of PLN-denominated bonds (close to 3 years). There is a downward trend in the average maturity of FX debt, but this can be attributed to the legacy nature of this segment (FX bond issuance dropped 4-fold in 2015-2018 vis-à-vis the 2004-14 average), and does not represent a conscious policy choice to shorten its maturity. These findings are consistent with the Ministry of Finance's debt management strategy (MoF, 2019), which clearly aims at stabilizing the average maturity and duration of local currency debt and reducing the share of FX debt.

\section{Figure 5}

\section{Distribution of outstanding PLN-denominated debt by maturity (in \%)}

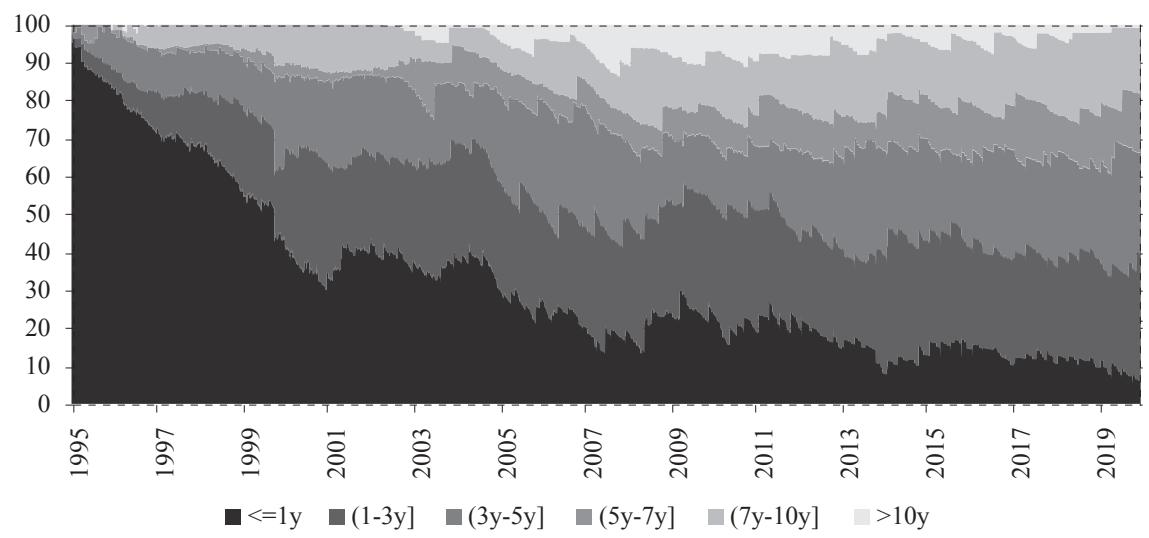

Source: Own elaboration based on MoF data.

\section{Figure 6}

Number of outstanding PLN-denominated bond issues by maturity

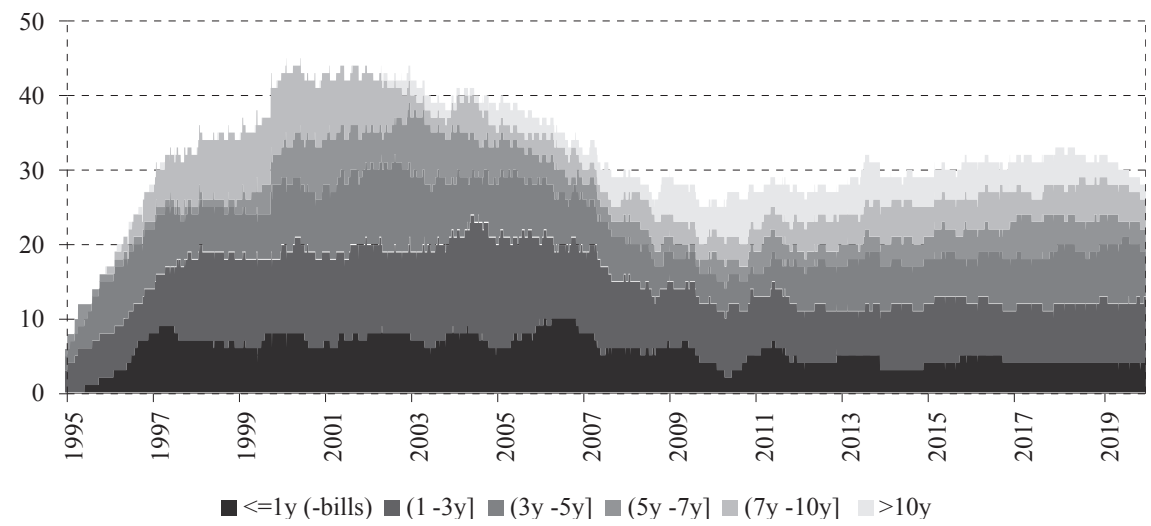

Source: Own elaboration based on MoF data. 
Taking a broader look - the steady increase in the size of local currency bond market was accompanied by the overall decrease in the number of available bond issues. As a result, the average outstanding size of a bond issue rose from PLN 822m in 1995 to PLN 8128m in 2005 and to PLN 18679m in 2018 (all values expressed in constant prices, base year 2016 - see figure 7 for a complete series). The redemption of securities owned by pension funds temporarily reduced the average issue size, but the difference quickly disappeared as debt continued to rise in the subsequent period. The distribution of issue sizes has historically been shifting rightward, with a thinner left-hand tail and a smaller number of limited-size bond issues. In fact, in July 2009 the distribution became negatively skewed and has remained so ever since. By then, multiple closely-maturing issues had already matured and the resumption of Treasury bill issuance allowed the MoF to reduce the number of separate Treasury bond issues. In the first post-GFC years, issuance remained high, but the large-scale purchases from non-residents (see the following chapter) allowed the MoF to extend debt duration again and curtail bill issuance again.

\section{Figure 7}

Average size of a PLN-denominated bond issue (millions of PLN, 2015 prices)

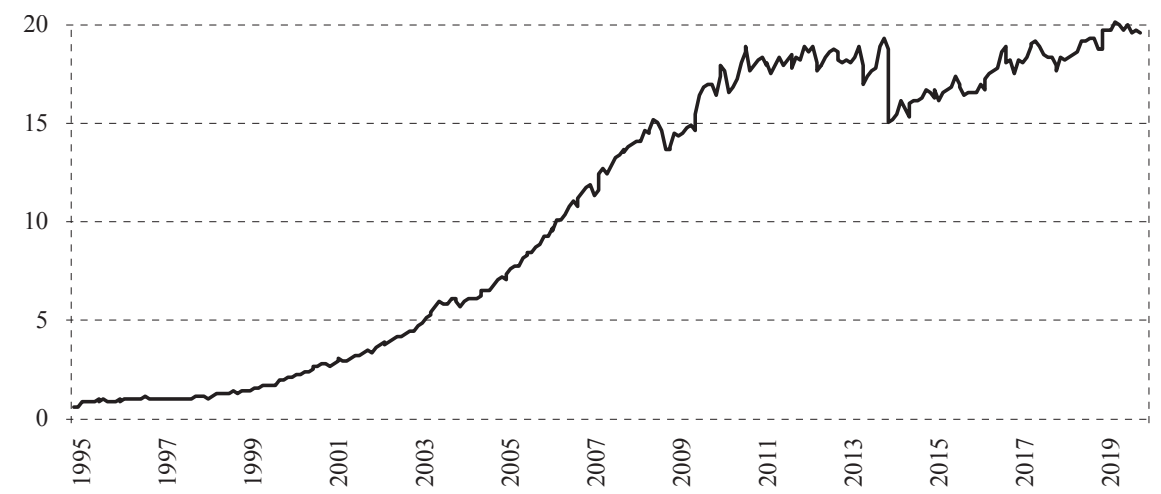

Source: Own elaborations based on MoF data.

The changes to issue size distributions were, on balance, enhancing market liquidity. Multiple studies on bond market liquidity (see: Tanner and Kochin, 1971; McCauley and Remolona, 2000; Galliani, Petrella and Resti, 2014; Gao, Jin and Thompson, 2018) have shown that issue size is positively correlated with liquidity. Thus, the consolidation of the Polish local currency bond market had several consequences: improvement in liquidity, greater transparency and investability.

\section{OWNERSHIP STRUCTURE}

The modern structure of Polish public debt ownership emerged as a result of the introduction of the new (1997) constitution, which barred the government from borrowing funds directly from the central bank. Hitherto, existing loans to the MoF ( $14 \%$ of total domestic debt) were, converted into bonds and gradually sold to market participants - by 2003 the NBP's portfolio of Polish government bonds was wound down to zero (Panfil, 2014). In addition, the nature of the NBP's open 
market operations has also changed - in the early 1990s Treasury bills were their primary instrument (Przybylska-Kapuścińska, 2003). Since then, the ownership structure of PLN-denominated bonds has been dominated by four key types of bondholders: foreign investors, commercial banks, local investment funds (including pension funds) and insurers - as of December 2019 those types of institutions held $88 \%$ of PLN-denominated marketable debt. The remaining $12 \%$ is distributed among households and non-financial companies as well as social security funds.

Since 2003, public debt ownership has undergone significant changes. In the precrisis period, the biggest accumulation in both nominal and relative terms occurred among pension funds, whose holdings rose from 13 to $25 \%$ of total marketable debt. Commercial banks' holdings, flat in nominal terms for several years, have only began to rise in 2007. Foreign ownership of PLN-denominated public debt remained essentially flat in nominal terms until early 2009. The era of quantitative easing and large-scale capital flows to emerging markets saw foreign holdings of PLN-denominated debt almost quadruple in absolute terms (from PLN 59 bn in March 2009 to PLN 207 bn in April 2013) and increase from 13 to 37\% of total (see figure 8). Another era was brought about by two key events: the "taper tantrum" episode and the subsequent shift in the Federal Reserve's monetary policy (for a detailed discussion of US monetary policy easing and tightening see Chari, Stedman and Lundblad, 2017; Fratzscher, Lo Duca and Straub, 2018). Finally, an important milestone is the 2013-2014 reform of private pension funds (Jakubowski, 2016).

\section{Figure 8}

Value (left panel, bn PLN) and share (right panel, \% of total) of banks and non-residents debt holdings
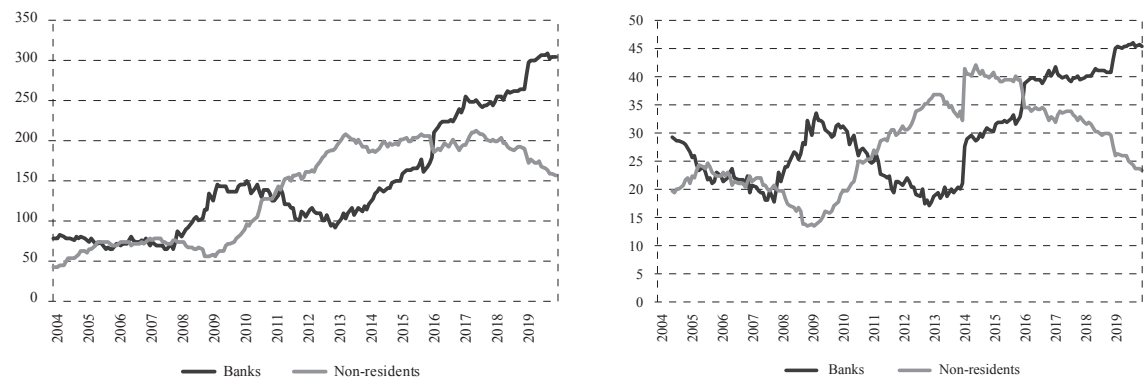

Source: Own elaborations based on MoF data.

From 2013 on, the amount of PLN-denominated debt held by non-residents has ebbed and flowed but remained essentially flat in nominal terms. The pension funds reform of 2013 (which came into force in February 2014) cancelled, among other changes, the private pension funds' entire portfolio of government bonds, thereby bringing its share in public debt to zero and mechanically raising the shares of other types of investors. The mantle of being the biggest net buyer of Polish government bonds over that period, both in absolute and relative terms 
must be awarded to commercial banks, whose holdings rose from PLN 91 bn in December 2012 (18\% of total) to PLN 305 bn in December 2019 (45\% of the total). The key factor behind this relentless rise in bank holdings of government debt has been the persistent decline in loan-to-deposit ratios and the rising capital of Polish banks, both resulting in greater demand for short-to-mid-term government bonds. This long-lasting trend was amplified in 2016 with the introduction of the bank asset tax, from which government bonds are exempt (UKNF, 2016; Wojciuk, 2017). In the end, the share of non-residents in Polish government debt is settling at levels close to EM or European averages: per BIS (2020), among EMs it varied between 5 and 54\%; according to Eurostat data, foreign ownership of general government debt in Poland stood at 44.1\% at end-2019, somewhat below the EU average of $49.3 \%$.

The changes in non-residents' share are inextricably linked to the overall external position of the Polish economy. The direction of causality is more debatable, though. Between 2006 and 2013 Poland has been running current account deficits of $4-6 \%$ of GDP. The financing of those deficits has changed drastically, though. In the run-up to the Global Financial Crisis and during the subsequent global recession the financial account was dominated by large FDI (3-4\% of GDP) and other flows (4-8\% of GDP, mostly through cross-border banking). The former source was curtailed after 2008 (to $1.5-2.5 \%$ of GDP) and the latter mostly dried up. The slack was taken by large-scale portfolio flows into Polish debt, which peaked at 5\% of GDP in 2010 and stood at 3\% of GDP until end-2012. Since 2014, the Polish current account balance has rarely shown deficits larger than $1 \%$ of GDP and portfolio flows into Polish debt remained negative throughout most of that period. On a net basis, portfolio debt flows reached -2\% of GDP in 2019 (a record-high outflow).

Overall stability in the average duration and maturity of the overall PLN-denominated bond stock hides some shifts within portfolios held by different types of investors. Analysing detailed data on bond holdings, we find that several trends can be identified. First, banks' holdings are primarily concentrated in the shorter maturity bracket, with an average duration in the 2.3-3.5-year range since 2006 and an average maturity in the 2.8-4.0-year range since 2006. Interestingly, the accumulation of PLN bonds since 2013 did not lead to any meaningful change in the characteristics of banks' portfolio (figure 10). Presumably, it conforms to regulatory and legal limits banks' asset and risk exposures are subject to. Second, only between mid-2015 and mid-2017 was there any rapid change in duration risk borne by foreign investors - over that period, the average maturity and duration of their portfolios rose by more than a year - the biggest such shift observed in our sample (figure 9). Insurers operating portfolios of longer-dating bonds (with average maturity of 5.2 years in December 2019) have seen a multi-year decline in their maturities and durations. The investment fund sector, having reduced its portfolio maturity in 2013 and early 2014, now appears to replicate the maturity structure of the overall outstanding debt closely. Finally, purchases of 
longer-dated bonds by households surged in 2011 and again in 2014, but their holdings remain small compared to other main types of PLN debt holders.

\section{Figure 9}

Average duration (left panel) and average maturity (right panel) of bond holdings (in years)
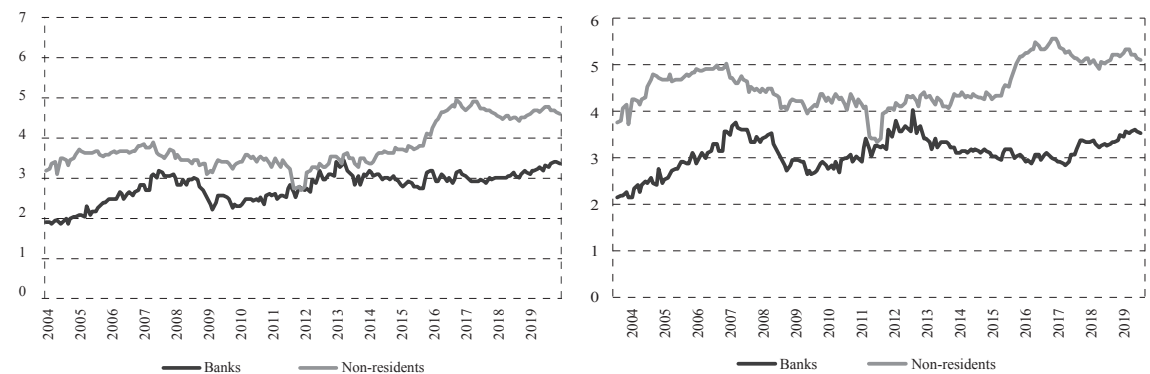

Notes: Average duration calculated only for fixed-rate and zero-coupon bonds of OK, PS, DS and WS series; average maturity was calculated for all PLN-denominated bond series.

Source: Own elaborations based on MoF data.

Finally, it is worth mentioning that the overall stability of non-residents' holdings of PLN-denominated debt has been accompanied with shifts in their geographical structure. Available data (MoF database on geographical origin of foreign investors on the local currency bond market starts in April 2014) indicate that over the period of 6 years the share of investors from the United States and several European locations has declined considerably. There was, however, a commensurate increase in the role of Asian investors (Japanese in particular) and central banks, whose identity is unfortunately unknown. By late 2018, the latter rose from 8.0 to $21.0 \%$ of the total non-residents' portfolio, only to fall back to $12 \%$ at the end of 2019 . HerfindahlHirschmann-type indices show a slight decline in the geographical concentration of foreign holdings of PLN debt holdings over the aforementioned 6-year period.

\section{CONCLUSIONS}

The Polish bond market has evolved considerably over the past decades and continued to do so recently - this applies to both the structure of bond supply and changes in bond demand. In several ways, its structural characteristics, such as the size relative to the whole economy, available maturity range and types of bonds marketable, have changed little over the past ten years. While the Polish local currency bond market - in a way - matured in the past decade, there have been important shifts in the structure of debt holders that did not impact either the supply profile or liquidity. In particular, recent years saw the complete dissolution of one large debt holder (private pension funds) and sharp increase in the role of another (local banks and foreign investors - the latter heterogeneous themselves). Building a liquid and large local currency bond market is crucial for developing countries, as it allows them to escape the notorious "original sin" and therefore improve their financial and macroeconomic stability. The Polish experience, 
however, points to the gradual nature of this process as all the major steps towards this goal were taken over several years. Additional prerequisites of a functioning bond market, such as a robust inflation targeting regime, successful disinflation and large enough pool of private savings are also present and they too unfolded over time. Moreover, even if a liquid and functioning local currency government bond market exists, some external vulnerabilities remain. Large swings in the amount and share of debt held by non-residents can, as Poland's example shows, still occur.

Our findings have implications for debt management strategies and their implementation. First, the reduction in the number of issues accompanied by raising issue sizes is net positive for liquidity and price discovery on the bond market. Therefore, governments should be encouraged to avoid market fragmentation and the cornerstone of an issuance strategy would be to limit the number of separate bond issues, while ensuring that a wide range of maturities is available to debt holders at all times. Second, compared to several peer markets, the Polish bond market lacks a sufficient number of inflation-linked securities, which limits their informational value. Third, rapid changes in the composition of debt holders are possible, especially if external factors are at play. However, this can occur within an unchanged issuance framework and purely through market forces. The Polish experience is one of falling interest rates and bond yields regardless of the composition of public debt holdings. Four, Polish experience shows that liquidity management can be improved by early repurchase of securities at auctions. This tends to increase debt service costs in an environment of falling interest rates, but by limiting the need to hold cash buffers, reduces the debt manager's operating costs in other areas. As an instrument of debt management, switch auctions tend to be less popular than regular auctions. However, Poland offers a case of consistent, uninterrupted use of switch auctions for almost twenty years. Finally, in open economies sovereign bond markets cannot be analyzed separately from broader macroeconomic trends, in particular, changes in the external balance of the country, foreign capital flows, and their determinants.

Several important questions can be raised. First, the exact impact of the changes in institutional environment, market structure and debt management practice on the liquidity of the Polish bond market, should be investigated and measured in a quantitative fashion. Second, the Ministry of Finance's long-standing issuance strategy might be investigated in greater detail as an avenue for further research. In particular, duration extension can be enhanced by utilizing favourable secondary market conditions (i.e. issuing more long-term debt when interest rates are low and the yield curve is flat). The extent to which actual issuance was operationalized this way is unknown at this stage and requires transaction and bond price databases to be cross-correlated. Finally, history is still being written and at the time of writing, additional factors have been influencing the functioning of the market (i.e. COVID-19 pandemic, significant issuance of government-guaranteed off-balance debt and unconventional monetary policies launched by the National Bank of Poland). A full accounting of their impact on Polish government debt 
market will occur in the future as these processes continue to unfold. Finally, in addition to domestic monetary policy, the impact of other countries' monetary policies on the liquidity, ownership structure and price dynamics of bonds should be considered. Poland, as a small open economy could be a prime example for such investigation.

\section{Disclosure statement}

No potential conflict of interest was reported by the author. 


\section{REFERENCES}

1. Aizenmann, J. and Pasricha, G. K., 2013. Net Fiscal Stimulus during the Great Recession. Review of Development Economics, 17(3), pp. 397-413. https://doi. org/10.1111/rode.12039

2. Arora, V. and Cerisola, M., 2001. How does US monetary policy influence sovereign spreads in emerging markets? IMF Staff papers, WP 00/148, pp. 474-498. https://doi.org/10.5089/9781451856811.001

3. Babczuk, A., 2002. Rozwój rynku obligacji skarbowych w Polsce (1989-2000). Prace Naukowe Akademii Ekonomicznej we Wrocławiu, (952 Inwestycje finansowe i ubezpieczenia-tendencje światowe a polski rynek), pp. 505-511.

4. Banaszewska, M., 2015. Foreign Investors on the Polish Treasury Bond Market in the Years 2007-2013. Prace Naukowe Uniwersytetu Ekonomicznego we Wrocławiu, (381 Financial Investments and Insurance-Global Trends and the Polish Market), pp. 26-35.

5. BIS, 2017. BIS Quarterly Review, September 2017. Basel: Bank of International Settlements.

6. Blommenstein, H., Elmadag, M. and Ejsing, J., 2012. Buyback and Exchange Operations: Policies, Procedures and Practices among OECD Public Debt Managers. OECD Working Papers on Sovereign Borrowing and Public Debt Management, (5). https://doi.org/10.1787/5k92v18rh80v-en

7. Bordo, M. D., Meissner, C. M. and Stuckler, D., 2010. Foreign currency debt, financial crises and economic growth: A long-run view. Journal of International Money and Finance,29(4), pp. 642-665. https://doi.org/10.1016/j.jimonfin. 2010.01.002

8. Bowman, D., Londono, J. M. and Sapriza, H., 2015. US unconventional monetary policy and transmission to emerging market economies. Journal of International Money and Finance, 55, pp. 27-59. https://doi.org/10.1016/j. jimonfin.2015.02.016

9. Brzoza-Brzezina, M., 2006. The information content of the natural rate of interest. The case of Poland. Economics of Transition, 14(2), pp. 391-412. https://doi.org/10.1111/j.1468-0351.2006.00255.x

10. Buchholtz, S., Chłoń-Domińczak, A. and Góra, M., 2019. Implementing nonfinancial defined contribution pensions in Poland. In: R. Holzmann [et al.], eds. 2019. Progress and challenges of non-financial defined pension schemes. Washington, DC: World Bank.

11. Burger, J. D. and Warnock, F. E., 2006. Local currency bond markets. IMF Staff papers, 53(1), 133-146.

12. Burger, J. D., Warnock, F. E. and Warnock, V. C., 2012. Emerging local currency bond markets. Financial Analysts Journal, 68(4), pp. 73-93. https://doi. org/10.2469/faj.v68.n4.4

13. Cantu, C., Goel, T. and Schanz J., 2020. EME government debt: case for concern? BIS Quarterly Review (June), pp. 15-16.

14. Chari, A., Stedman, K. D. and Lundblad, C., 2017. Taper tantrums: QE, its aftermath and emerging market capital flows. NBER Working Paper, No. w23474. https://doi.org/10.3386/w23474 
15. Ciak, J. and Górniewicz, G., 2010. Bony i obligacje skarbowe jako instrumenty finansowania deficytu budżetowego w polsce. Studia Prawno-Ekono miczne, (82), pp. 241-266.

16. De Crombrugghe, A. and Lipton, D., 1994. The government budget and the economic transformation of Poland. In: The Transition in Eastern Europe, Volume 2: Restructuring. Chicago, IL: University of Chicago Press, pp. 111-136.

17. Eichengreen, B., Hausmann, R. and Panizza, U., 2003. The pain of original sin. Other People's Money: Debt Denomination and Financial Instability in Emerging Market Economies. Chicago: University of Chicago Press. https:// doi.org/10.7208/chicago/9780226194578.003.0002

18. Eichengreen, B., Hausmann, R. and Panizza, U., 2007. Currency mismatches, debt intolerance, and the original sin: Why they are not the same and why it matters. In: Edwards, S. ed. 2007. Capital controls and capital flows in emerging economies: Policies, practices and consequences. Chicago, IL: University of Chicago Press. https://doi.org/10.7208/chicago/9780226184999.003.0004

19. Fabozzi, F., 2005. Handbook of fixed income securities. New York, NY: McGraw-Hill.

20. Fratzscher, M., Lo Duca, M. and Straub, R., 2018. On the international spillovers of US quantitative easing. The Economic Journal, 128(608), pp. 330-377. https://doi.org/10.1111/ecoj.12435

21. Fultz, E., 2012. The retrenchment of second-tier pensions in Hungary and Poland: A precautionary tale. International Social Security Review, 65(3), pp. 1-25. https://doi.org/10.1111/j.1468-246x.2012.01434.x

22. Galliani, C., Petrella, G. and Resti, A., 2014. The Liquidity of Corporate and Government Bonds: Drivers and Sensitivity to Different Market Conditions. Brussels: Joint Research Center. https://doi.org/10.2788/70146

23. Gao, J., Jin, J. and Thompson J., 2018. The Impact of Government Debt Supply on Bond Market Liquidity: An Empirical Analysis of the Canadian Market. Bank of Canada Staff Working Paper, No. 2018-35. https://doi.org/10. 2139/ssrn.3176181

24. Garbade, K. D. and Rutherford, M. 2007. Buybacks in Treasury Cash and Debt Management. Federal Reserve Bank of New York Staff Report, No. 304. https://doi.org/10.2139/ssrn. 1022669

25. Gürkaynak, R. S., Sack, B. and Wright, J. H., 2010. The TIPS yield curve and inflation compensation. American Economic Journal: Macroeconomics, 2(1), pp. 70-92. https://doi.org/10.1257/mac.2.1.70

26. IMF, 2010. Fiscal Monitor, November 2010. Fiscal Exit: From Strategy to Implementation. Washington, DC: International Monetary Fund. https://doi. org/10.5089/9781616350475.089

27. IMF, 2011. Republic of Poland: Selected Issues. Washington, DC: International Monetary Fund. https://doi.org/10.5089/9781455295722.002

28. IMF, 2017. World Economic Outlook, October 2017. Seeking Sustainable Growth. Washington, DC: International Monetary Fund. https://doi.org/10. 5089/9781484328095.081 
29. Jakubowski, S., 2016. Proces wygaszania kapitałowej części ubezpieczenia emerytalnego. The Central European Review of Economics and Management, 16(1), pp. 73-84. https://doi.org/10.29015/cerem.171

30. Jakubowski, S., 2017. Ewolucja lokat OFE w dłużne papiery wartościowe zagadnienia prawne, finansowe i ekonomiczne. Krytyka Prawa, (2), pp. 54-69. https://doi.org/10.7206/kp.2080-1084.150

31. Jeanne, O., 2003. Why do emerging markets borrow in foreign currency? IMF Working Paper, WP/03/177. https://doi.org/10.5089/9781451858891.001

32. Klimek, N., 1998. Obligacje skarbowe jako instrument finansowania deficytu budżetowego. Zeszyty Naukowe Uniwersytetu Szczecińskiego. Prace Katedry Makroekonomii, (2), pp. 99-109. https://doi.org/10.15611/pn.2016.437.19

33. Łuszczyk, M., 2015. Zmiany w funkcjonowaniu otwartych funduszy emerytalnych - implikacje dla finansów publicznych w Polsce. Studia Ekonomiczne. Zeszyty Naukowe Uniwersytetu Ekonomicznego w Katowicach, 223, pp. 44-53. https://doi.org/10.33119/se.2017.309

34. Marchesi, S., 2006. Buybacks of domestic debt in public debt management. The European Journal of Finance, 12(5), pp. 379-400. https://doi.org/10.1080 /13518470500459931

35. McCauley, R. and Remolona, E., 2000. Size and liquidity of government bond markets. BIS Quarterly Review (November), pp. 52-60.

36. McKinnon, R. and Schnabl, G., 2004. The East Asian dollar standard, fear of floating, and original sin. Review of Development Economics, 8(3), pp. 331360. https://doi.org/10.1111/j.1467-9361.2004.00237.x

37. Medeiros, C., Polan, M. and Ramlogan, P., 2007. A primer on sovereign debt buybacks and swaps. IMF Working Paper, No. WP/07/58. https://doi.org/ 10.5089/9781451866223.001

38. Mehrotra, A. N., Miyajima, K. and Villar, A., 2012. Developments of domestic government bond markets in EMEs and their implications. BIS Paper (67c).

39. MoF, 2019. Strategia zarządzania dtugiem sektora finansów publicznych $w$ latach 2020-2023. Warszawa: Ministerstwo Finansów.

40. Morck, R., Yeung, B. and Yu, W., 2000. The information content of stock markets: why do emerging markets have synchronous stock price movements? Journal of Financial Economics, 58(1), pp. 215-260. https://doi.org/10.1016/ s0304-405x(00)00071-4

41. NBP, 2002. Rynek finansowy w Polsce 1998-2001. Warszawa: Narodowy Bank Polski.

42. NBP, 2004. Rozwój systemu finansowego w Polsce w latach 2002-2003. Warszawa: Narodowy Bank Polski.

43. NBP, 2018. Rozwój systemu finansowego w Polsce w 2017 r. Warszawa: Narodowy Bank Polski.

44. Olszański, P., 2002. Historia polskiego zadtużenia międzynarodowego na tle wydarzeń społecznych $i$ politycznych. Monografie i Opracowania/Szkoła Główna Handlowa, 513. Warsaw: Szkoła Główna Handlowa. https://doi.org /10.15290/ose.2017.03.87.03 
45. Panfil, P., 2014. Nabywanie skarbowych papierów wartościowych przez NBP. Annales Universitatis Mariae Curie-Skłodowska, Sectio H, Oeconomia, 48/4, pp. 177-184. https://doi.org/10.17951/h.2014.48.4.177

46. Prasad, E. S., Rajan, R. G. and Subramanian, A., 2007. Foreign capital and economic growth. Brookings Papers on Economic Activity, 38(1), pp. 153230. https://doi.org/10.1353/eca.2007.0016

47. Przybylska-Kapuścińska, W., 2003. Operacje otwartego rynku w Polsce w latach 1993-2002, Ruch prawniczy, ekonomiczny i socjologiczny, 65(4), pp. 89-116.

48. Rai, V. and Suchanek, L., 2014. The effect of the federal reserve's tapering announcements on emerging markets. Bank of Canada Working Paper, No. 2014-50.

49. Rybiński, K., 2000. Wpływ polityki pieniężnej na proces dezinflacji w Polsce. Bank i Kredyt, (7-8), pp. 56-79.

50. Tanner, J. E. and Kochin, L. A., 1971. The Determinants of the Difference Between Bid and Ask Prices on Government Bonds. The Journal of Business, 44(4), pp. 375-379. https://doi.org/10.1086/295399

51. UKNF, 2016. Syntetyczna informacja na temat wpływu podatku od niektórych instytucji finansowych na sytuację banków komercyjnych. Warszawa: Urząd Komisji Nadzoru Finansowego.

52. Walczyk, K., 2001. Finanse publiczne w Polsce w latach 1991-2000 a stabilizacja gospodarki. Prace i Materiały Instytutu Rozwoju Gospodarczego SGH, 70, pp. 29-50.

53. Wasilewska, H. and Korczak, T., 1998. Obligacje skarbowe jako instrument rynku kapitałowego. Bank $i$ Kredyt, 4, pp. 37-44.

54. Wasilewska, H., 1998. Skarbowe papiery wartościowe jako instrument długu publicznego. Prace Naukowe Instytutu Nauk Ekonomiczno-Społecznych Politechniki Wrocławskiej. Studia i Materiaty, 21 (56 Instrumenty rynkowe w gospodarce: problemy transformacji), pp. 68-81.

55. Wojciuk, M., 2017. Wpływ podatku od niektórych instytucji finansowych na zachowania banków komercyjnych w Polsce. Optimum. Studia ekonomiczne, 90(6), pp. 27-41. https://doi.org/10.15290/ose.2017.06.90.04

56. Wurgler, J., 2000. Financial markets and the allocation of capital. Journal of Financial Economics, 58(1-2), pp. 187-214. https://doi.org/10.1016/s0304$405 \mathrm{x}(00) 00070-2$

57. Zemburam, W., 2006. Dług publiczny i jego obsługa w Polsce w latach 19961999. Studia Ekonomiczne/Akademia Ekonomiczna w Katowicach, 43, pp. 95-113.

58. Ziarko-Siwek, U., 2012. Efekt przetargu na wtórnym rynku obligacji skarbowych w Polsce w latach 2001-2010. Ruch Prawniczy, Ekonomiczny i Socjologiczny, 1, pp. 167-190. https://doi.org/10.14746/rpeis.2012.74.1.11 
